\title{
OUR MANDATE IN NORTH TOGOLAND
}

\section{PART II}

THE Bimoba are a very little known tribe. They speak a dialect akin to the Gruma branch of the Moshi or Dagomba language, and certainly to be included in the Voltaic group noticed and so named by Mr. Delafosse. They do not seem here to be smelters of iron as the Kusasi and Busansi; but they have a great pottery industry. At each village one sees the furnaces used for that purpose. They are not native to this part. Their original home is unknown, but the people under our protection came from the east, driven from Mir and Nano by the Ashanti invaders. Here, indeed, is an interesting glimpse into the history of that warrior tribe. Till now the history of the Ashanti, excepting in so far as his relations with European Powers are concerned, is practically unknown or rather unrecorded, and perhaps the following tradition of the Bimoba may not only be of interest but also of value.

Some two hundred years ago there were two claimants to the skin or throne of Mamprusi : Kogodana and Yigandana. The former, unable to overwhelm his rival, sent for help to Ashanti. His request was granted and an army from the south came to his assistance. Their leaders were Natabe, Sangwana and Garadima. (I don't know whether these are Twi or Dagomba names.) They first showed their ally how to fortify the town of Nalerigu, and themselves built a wall of mud strengthened with shea-butter round the place, and having defeated Yigandana, demanded a land in which to settle.

Kogodana pointed out to them Sansane Mangu. They agreed to this and marched to this place, now the French headquarters, on the Oti river. Here they met a wild naked race whom they easily overwhelmed.

To digress a little, it is of interest as supporting the quasitruth of this tradition, the Sansane Mangu people and the 
Tchokosi not only speak a dialect of Twi, but name their children after the days of the week, Kwesi, Kojo, etc., as in Ashanti. Moreover, this great Ashanti invasion is recorded in the Grumshi (Kasena and Nankanni) traditions. The people of Zeko even trace their origin to a wounded Ashanti left behind by the retiring army. How similar this last is to our own former belief of Trojan extraction.

Firmly established at Sansane, the Ashanti developed a great slave-raiding business. Naturally their raids tended to go further and further afield. Eventually they reached the then Bimoba country, and these unfortunate people, though under the protection of the Mamprusi chief, were forced to seek refuge close to Nalerigu and thus came to inhabit this part of our mandate. The present chief of Solotigu is the sixth since this flight, which must therefore have been some sixty to a hundred years ago.

Eventually the Ashanti were defeated by a combined force of Dagomba, i.e. Mamprusi and Kusasi, at a place called Yargunga, somewhere in French territory to the north of Bozku. I do not think this could be the same defeat recorded in Grunshi tradition, for sixty years ago the Zaberma raiders were ravaging that country, and their doings are well known in detail to this day, whereas the Ashanti tradition is very vague, and therefore presumably much more ancient.

The Bimoba live in grass-roofed huts of the usual round type. There are usually five huts to a compound. The entrance to the hut is of the Mamprusi pattern, being a door through one of the huts, which is put to many uses as mentioned above. Outside the compound are two roughly squared granaries about ten feet high. One containing the thrashed grain is raised off the ground about eighteen inches and stands on roughly hewn logs, which themselves are set on stones so that damp and ants may not easily ruin the store. The other is on the ground and is used for unthrashed grain, beans and ground-nuts. In front of the granaries is a hard beaten mud circle, on which the tassels of guinea-corn and ears of millet are dried and later thrashed. Cattle are kept in zaribas and tended by Fula men. Goats and sheep and poultry live with their owners. The number of dogs is remarkable. One notices 
a curious mattress-like carpet at each door, made of the stalks of the fan-palm leaves tied together.

The women are not clothed, being content with bunches of leaves. Instead of the finely woven and coloured grass girdle of the Kusasi, they use a quantity of strings made of woven grass and all dyed black with which to suspend their leaves. The men are ordinarily clothed, in loin-cloth and sleeveless jumper of native cloth reaching half-way down the thigh. But I noticed particularly a form of adornment which I have not. seen elsewhere. Many of the youths tie round their ankles and half-way up their calves the dried leaves of the fan-palm, giving the appearance of dirty white gaiters.

One of the most striking features of these villages is that outside practically every compound is growing a particular bush. The plant resembles a baobab in its grey grotesqueness, and in February is covered with a mass of large pink flowers. The tapering branches are soft and leathery like tentacles. It is called Saa-tesaga by the Bimoba (tornado-thunder) and is looked upon as a deterrent for lightning. I do not know whether this is a cactus or not. ${ }^{1}$ Excepting in the Tong Hills I have not met it; I believe Capt. C. H. Armitage, now Governor of the Gambia, when Chief Commissioner of the Northern Territories, took specimens to Kew.

This is far from the only "fetish" outside the compounds. There are many of all sorts, but interpretation being difficult and shyness a still greater obstacle, one could not learn much. These sacrificing spots, calabashes, stones, forked trees, pots, etc., are far more numerous than I have encountered anywhere in the Northern Territories. Most remarkable is Poyonna, a wooden idol carved from the fan-palm. It resembles a man, and is about five feet high with arms and legs. It has no features to its face and is the "fetish" to which all sacrifice before going hunting in the bush. In other respects the appearance of a group of compounds is not greatly different. Farms are made right round the hut group, and the crops are the usual guinea-corn, millet, beans and ground-nuts. Here and there yams are tried, but with little success. It would appear that the great Gambaga scarp is a barrier for agriculture as it

1 There are no cacti indigenous to Africe.-Eds. 
is for tribes and climate, a definite line of demarcation in every respect.

Following more or less closely to the new boundary one passes village after village. The country is badly cut up by the rains into deep narrow nullahs, but as one reaches the summit of each undulation the scenery is really magnificent. The scarp now rears itself like some distant mountain range, the eastern bank of the Biankuri is backed by a small sharply broken range covered with forest, and in the far distance one can make out yet other ranges of hills. To the west and north there is nothing but the rolling waves of tree-tops interspersed with high brown patches denoting the whereabouts of villages. From time to time one passes groups of ruined and deserted compounds. These are the grim witnesses to a devastating plague of some twenty-five years ago, which just before the advent of the white man decimated the country. From the tradition of its symptoms it would seem to have been the fatal cerebro-spinal meningitis which so often visits these parts.

As I was riding quietly along the path, there came along a party of five men, clad only in kauri-bedecked strips of cloth, a striking sight, since all men here are clothed usually in native jumpers or at least drawers. When they reached me they bent to the ground and danced past, crouching and greeting me with a low guttural growl. This naturally roused my curiosity, and one of the sons of the chief of Solotigu provided me with the following information.

These men are members of a secret society which is to be found in most villages. The society is entirely of Bimoba origin, members of which are known as Konne (pl. Konse). After reaching puberty all young men are eligible. They are taken to an old man, owner of the society's bari or medicine, and therefore local head of the Konse. After three days their entry is approved, and a house of grass mats is erected for them near the Lari's (head of the Konse) compound. Here the candidate remains secluded for four months. He is taken there at night and no man may see his going. He may not come out till the period of seclusion is past, and his wants are attended to by a boy and girl who are named his father and mother. The owner of the bari renames them, and by these 
names only may they be known after their re-entrance into society. To mention their original name is death from sickness in no long time. These Konse names are: Lari, Sangso, Duti, Kombete, Kolaa, Lamboa, Sambeg, Samwog, Bonbog. They learn a special language unintelligible to the uninitiated. It is certainly a weird language, sounding like so many growls, but when sung in chorus is of an extraordinarily pleasant hearing.

They learn, too, a series of dances and the strange manner of walking first noticed by me, crouching towards the ground and skipping or dancing rather than walking along. And they learn to use their left hand with which to eat meat and not as is customary the right. This is during the probationary period of four months. But even more interesting than this subversion of custom is the fact that except for meat they may use no hands at all for eating. Their " mother "feeds them. The food usually is millet or guinea-corn porridge soaked in water. She ladles the food out with a calabash which she holds to their lips. Goats-flesh and fish are forbidden during this time.

If a Kusasi youth wishes to become a member he has to undergo a rather frightening ordeal. $\mathrm{He}$ is cut with a knife and medicine is inserted in the wounds. Thereby he is reduced to unconsciousness for a long time. "He dies for five days" is the expression used. They then anoint him with other medicine and he returns to consciousness.

When the four months' seclusion is completed the father of the candidate provides a feast for him and his "father and mother" attendants, and gives to the Lari three fowls, 400 kauri, four pots of native beer, four calabashes of food and three pots of cooked meat. During the ensuing month, the first after their liberation, they give themselves up to dancing and feasting. They are terribly excited at this time and cannot remain at rest. I saw one outside the chief of Solotigu's compound and he was ever on the move and looked like one half-crazed.

The season for the initiation period is naturally the dry season, lest farming should suffer, and I was fortunate enough to be at Solotigu just after the seclusion period had ended and during the month of festivity. The chief gave me the pleasure 
of witnessing a dance. We had first to hold a political palaver and the dancers were very restless. One fainted from excitement-a not unusual event among these savages.

Freed from duty we adjourned to the shade of a locustbean tree and the dance began.

There were fourteen dancers attended by their late " mothers." They were covered with kauri-a band of these shells round the forehead, several thick necklaces, some hanging well below the waist. Five bands of kauri girdled their loins, and tucked in behind was the skin of an oribi with the hair side showing, whilst in front was a small blue loin-cloth almost covered with strings of kauri, which hung from ropes of the same shell that encircled the neck. Each, too, had a leather bag decorated with the same shell hanging in front. Wristlets and armlets were of the same design, and anklets and bands round the top of the knee were of iron. On either arm above the elbow was a wooden ring, and on the ankles were iron bangles hung about with loose iron rings which rattled as they danced. In addition every dancer wore necklaces of beads of European manufacture.

On the left shoulder they all carried axes and in their right hands a horse-tail, of which the handle was studded with kauri. The left hand grasped the axe-handle and was armed with a dagger, of which the hilt passed over the palm and was still further guarded by being tied with a leather thong to the leather wrist shields which every bowman must wear; on the right hand a sharply pointed knuckle-duster and an iron ring on the thumb. Earrings of iron and a necklace of threaded iron rings completed the dress, the back being crossed with kauri bands. The tout ensemble was not only strikingly picturesque but extraordinarily attractive.

Music for the dance was supplied by drummers, who were clothed ordinarily. The drums resemble roughly trimmed side drums and were painted red, white and black in stripes. They all showed traces of sacrifices to them, blood and feathers remaining stuck on their sides.

The dance was accompanied by a song in the guttural growling speech of the society. So far as I could make out the steps were not intricate, but the time was excellent. A short step forward with the left foot, the right one then came to its 
heel; a second short step with the left, the dancer then leapt about a yard on the left; the right foot came up and a third short step with the left. When the dance ceased each covered his features with the horse-tail and his attendant "mother" wiped the sweat from his brow with her hand.

A second dance followed. Each gave up his horse-tail and took a drawn sword of native manufacture. The scabbard was slung on the left hip. I could not make out the step. From time to time the sword was thrust into the sand and the dancers bent over them, all the time chanting in their guttural tones. They suddenly massed together with sword-points on the ground and bodies bent bowed before me. I was told they were saluting me and asking leave to go. They sang a chant, almost Gregorian, whilst awaiting my dismissal. I was nearly tempted not to let them go, but had pity on them, for the sun was high and the heat intense. They then pranced or danced off to their Lari's house.

It is worthy of note that once initiated a member is considered of a fit age to marry. Nowhere else in North Mamprusi is this society or any other similar society to be found. It would be interesting to know whether this at all resembles the Moshi Wango.

When a Konne dies it is said that his spirit returns while his comrades are dancing in his honour. He will seize all his former dancing dress and dance alone in his former hut. All outside will hear him stamping and his dancing irons rattling; but they cannot see him, and until his Lari has begged him to depart, telling him how the women and children are afraid and weeping, he will not cease. But then he hears his old tutor and goes willingly to his rest.

On leaving Solotigu one leaves the Bimoba country behind, and riding along a road made by the Germans one re-enters the almost treeless undulating country of scattered compounds typical of the Kusasi and Busansi and of long settlements. Here and there are short belts of shea-bush, but these gradually disappear as one proceeds northward until-Timpani, Kagbiri and Buguri having been passed-one sees again the sacred wood of Pusiga and the little eminence Motanga.

a. W. Cardinali. 